\title{
The Feasibility of the Kancingan House Structure in Merauke City
}

\author{
Sari Octavia ${ }^{1}$, Henry Soleman Raubaba ${ }^{2}$, Yashinta Irma Pratami Hematang ${ }^{3}$, Anton Topan ${ }^{4}$ \\ Architecture Department \\ Universitas Musamus \\ Merauke, Indonesia \\ 1'sariwidianto2408@gmail.com, ${ }^{2}$ henry_soleman@unmus.ac.id, ${ }^{3}$ yashimta@unmus.ac.id, ${ }^{4}$ anton@ unmus.ac.id
}

\begin{abstract}
Kancingan house is a house made of wood materials as its main structure but the walls are still made of bricks. The use of wood as the concrete-replacing materials is due to the relatively lower cost than the permanent structure made of concrete as the main structure since the concrete materials composed of high-quality sand and gravels are not available in Merauke City, so that the materials should be imported from other city, such as Palu or Surabaya City. This problem makes concrete expensive in Merauke City. This research aimed to analyze the Kancingan house in terms of the feasibility of its building structure. It is a quantitative research which was conducted by conducting field observation, image recapturing, and structure analysis by using SAP 2000. The results showed the Bending strength ( $\sigma \mathrm{lt}) \leq f \mathrm{~b}^{\prime}$ or olt $=\mathbf{2 8 5 , 8 1 9} \leq 1100 \mathrm{~kg} / \mathrm{cm} 2$. For bending control, with a provision of $f x \leq f$ permit $(1 / 200$ of the span), the structure of truss of kancingan house in this research is $f x=12,64 \mathrm{~mm} \leq 13,75$. The tensile strength corrected in the truss is or $T^{\prime}=7.28$ tonnes. In the ring balk of the kancingan house building, the bending strength is greater than the maximum moment due to seismic load is or $M^{\prime}>M=1795,2 \mathrm{Kg} / \mathrm{m}$ $>43,55 \mathrm{~kg} / \mathrm{m}$. The $8 / 8$ column meets the slenderness ratio of Le/d $=25>50$ with a stability factor greater than the compressive strength works in column $M^{\prime}=179502 \mathrm{~kg} / \mathrm{m}>M=43.55 \mathrm{~kg} / \mathrm{m}$ and the magnitude of factored load imposed to the column is $P^{\prime}=11010,96 \mathrm{~N}$.
\end{abstract}

\section{Keywords—kancingan house; wood structure}

\section{INTRODUCTION}

House is a shelter and is in the second priority that must be achieved for safety purposes before fulfilling other higherpriority needs. House is a necessity for self and family that separates one family from other families, [1]

The need for house is the main thing in big cities, including Merauke City which is one of the cities in Papua Province in which the development of the city is relatively rapid. The high need of providing a shelter is not in line with the availability of natural materials, such as sand and gravel. This is the reason behind the development of kancingan house of which main structure is made of wood and the wall is made of bricks.

Kancingan house is a house made of wood materials as its main structure but the walls are still made of bricks. The use of wood as the concrete-replacing materials is due to the relatively lower cost than the permanent structure made of concrete as the main structure since the concrete materials composed of high-quality sand and gravels are not available in Merauke City, so that the materials should be imported from other city, such as Palu or Surabaya City. This problem makes concrete expensive in Merauke City. Wood can be used in almost all parts of a building, such as foundation, frame, floor and wall, and roof. The advantages of using wood materials are, among others, better strength, visual advancement, sound and heat proof, and weather-resistant. In addition, the ease and affordability of prices are the other factors of using wood materials [2]. Wood is also has orthotropic which distinguishes from other materials, and has 3 axes; longitudinal, tangential and radial; compared to isotropic materials, such as concrete and steel [3].

The results of previous studies examined the aesthetics of kancingan house showed that the wood and brick bonding in kancingan house becomes the main problem in terms of aesthetics, because wood, as an organic material, will experience shrinkage and deformation and this is what greatly disrupts the appearance of the walls of the building, so that there is a need of special treatment on wood materials when applying wood materials to buildings, so that the shrinkage can be reduced.

The purpose of this research is to analyze the kancingan house in terms of the feasibility of the building structure. The structure of the building is the arrangement of parts of the building that are imposed the main load or construction, without considering whether the construction is seen as a building structure or not. In general, the building structure consists of foundation, walls, columns, floors and roof trusses [4]. The data were analyzed using computerized simulation using SAP application and through literature study. The research was conducted in Merauke City by taking some house buildings as the sample.

\section{MATERIALS AND METHOD}

\section{A. Time and Location of Research}

This research was conducted in June 2018 in Merauke City, Papua, by taking some house buildings as the sample accross Merauke City. 


\section{B. Sources of Data}

The data used in this study were obtained from observation, documentation, and literature study on wood structure and kancingan house.

\section{Research Design}

This research is a qualitative research with the following stages of research: 1) taking some kancingan houses as the sample, 2) direct field observation, 3) image capturing, 4) literature study, 5) computerized simulation using SAP 2000.

The sample houses were then made into images using the AutoCAD program and were then reconstructed for the structural system and analyzed using SAP 2000.

\section{Population and Sample}

The population in this study was community houses accross the Merauke Regency, namely in Okaba, Tanah Miring and Merauke Districts. The sample houses taken were the type $36 \mathrm{~m}^{2}$ houses with the following materials: 1). 5/10 timber trestle with E15 quality wood type according to the Indonesian National Standard with an elastic modulus of 7000 Mpa. 2) 5/7 timber purlin with E15 quality wood according to the Indonesian National Standard. 3) 8/8 timber ring balk with meranti wood. 4) $8 / 8$ wooden columns with meranti wood. 5) $4 / 8$ wall beam with meranti wood. 6) partition walls using bricks. 7) $8 / 8$ wood sloof with meranti wood. 8) foundation using bricks. 9) roof cover material using zincalume soka.

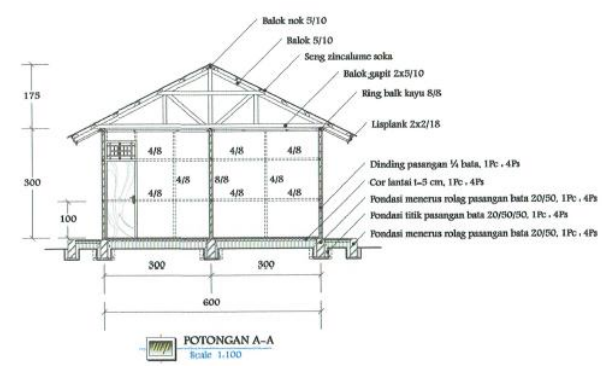

Fig. 1. The cross view of kancingan house

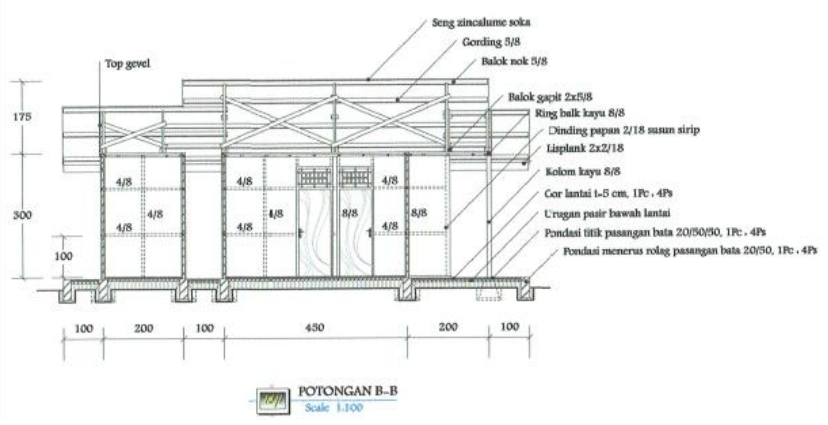

Fig. 2. Horizontal view of kancingan house

\section{E. Data Collection}

The variables used in this research include blueprint, structure and type of materials used in kancingan house.

\section{F. Data Analysis Method}

The analysis method used was qualitative-descriptive, where the results of observations and literature studies were explained in details. The direct observation data were taken directly in the field, consisted of images which were then interpreted in the form of texts and re-captured images.

\section{RESULT}

\section{A. The Truss}

In general, the truss in kancingan house is similar to common house which is a part of the roof that serves as a cover for protecting the inside of the house from heat of the sun and rain. The more specific, the roof truss function is to receive the load by its own weight, namely the trestle load and vertical directed cover material then forward it to the columns and foundation, and can function to withstand the horizontal directed wind pressure load [5]. Materials that are widely used in roof construction, especially for house buildings, come from the nature, namely wood and there are only few industrial materials used [6].

In kancingan house which is the object of research, the roof is composed of E15 quality timber trestle according to the Indonesian National Standard with a size of 5/10, 5/7 timber purlin, 5/10 diagonal beam (balok skor), 5/10 clamp (balok gapit), gable beam $5 / 10$ and zincalume soka roof. The roof slope is 300 , the distance between the trusses is $2,75 \mathrm{~m}$, the purlin distance is $0,7 \mathrm{~m}$. See figure 1 . In order to find out the amount of load that works on the roof, then the calculation analysis is done using SAP $2000 \mathrm{~V} .11 .0$ to the roof load, the load of trestle and wind load by using 3 kinds of loading combinations, namely: 1) $1.4 \mathrm{D}, 2) 1.2 \mathrm{D}+1.6 \mathrm{~L}, 3) 1.2 \mathrm{D}+$ $0,5 \mathrm{~L} \pm 1.3 \mathrm{~W}$. After that, a frame model was created in SAP 2000 using 3 types of combinations, see figure 4, then bending strength control was made by applying the reliability of wood material with E15 quality and obtained the calculation of olt = $285,819 \mathrm{Kg} / \mathrm{cm} 2$, and bending control $f \mathrm{x}=12,64$. To control the tensile resistance, a calculation was made with the control strength resulted from SAP analysis of $728,84 \mathrm{~kg}$, (see figure 4) and obtained trestle using E15 quality wood resulting in the corrected tensile resistance of $\mathrm{Ft}^{\prime} \mathrm{x} \mathrm{An}=8,096 \mathrm{Kg}$. In order to check the slenderness ratio on the compressive rod with compressive strength of 398,96 see table 2 , resulted in Le/d = 11,428 and stability factor of $280,20 \mathrm{Kg}$.

TABLE I. LOAD WORKS ON ROOF

\begin{tabular}{|l|l|l|l|}
\hline $\begin{array}{c}\text { Live Load ( } \\
\text { taking P=100 } \\
\text { Kg) }\end{array}$ & \multicolumn{1}{|c|}{ Dead Load } & Wind Load & \multicolumn{1}{|c|}{ Seismic load } \\
\hline $\mathrm{Px}=50 \mathrm{~kg} / \mathrm{m}$ & $\begin{array}{l}\text { Roof Cover } \\
\text { Load =25,2 kg }\end{array}$ & $\begin{array}{l}\mathrm{W} 1 \mathrm{y}=20,525 \\
\mathrm{Kg}\end{array}$ & $\begin{array}{l}\text { Brick Wall = 851,36 } \\
\mathrm{Kg}\end{array}$ \\
\hline $\mathrm{Py}=86,6 \mathrm{~kg} / \mathrm{m}$ & $\begin{array}{l}\mathrm{Purlin}=12,375 \\
\mathrm{Kg}\end{array}$ & $\begin{array}{l}\mathrm{W} 1 \mathrm{x}=11,85 \\
\mathrm{Kg}\end{array}$ & $\begin{array}{l}\text { Timber/wood } \\
\text { column+wall frame } \\
=60,48\end{array}$ \\
\hline $\begin{array}{l}\mathrm{Mx} 2=29,66 \\
\mathrm{~kg} / \mathrm{m}\end{array}$ & $\begin{array}{l}\text { Truss = 17,37 } \\
\mathrm{Kg}\end{array}$ & $\begin{array}{l}\mathrm{W} 2 \mathrm{y}=41,051 \\
\mathrm{Kg}\end{array}$ & $\begin{array}{l}\text { Roof load = 878,16 } \\
\mathrm{kg}\end{array}$ \\
\hline $\begin{array}{l}\mathrm{My} 2=17,125 \\
\mathrm{~kg} / \mathrm{m}\end{array}$ & Plafond =55 kg & $\mathrm{W} 2 \mathrm{x}=23,7 \mathrm{Kg}$ & \\
\hline
\end{tabular}




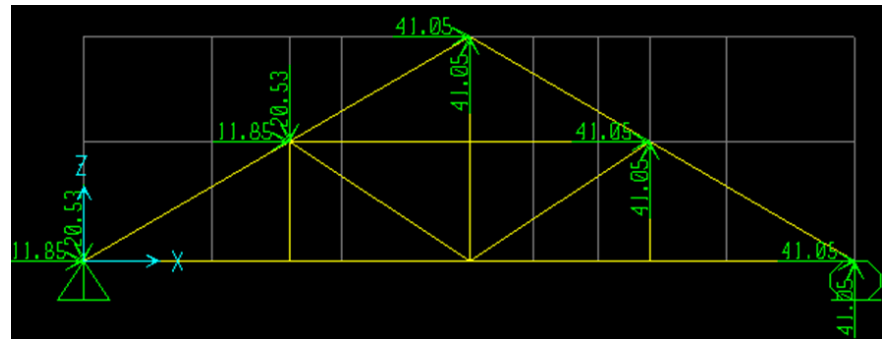

Fig. 3. Loading due to wind load

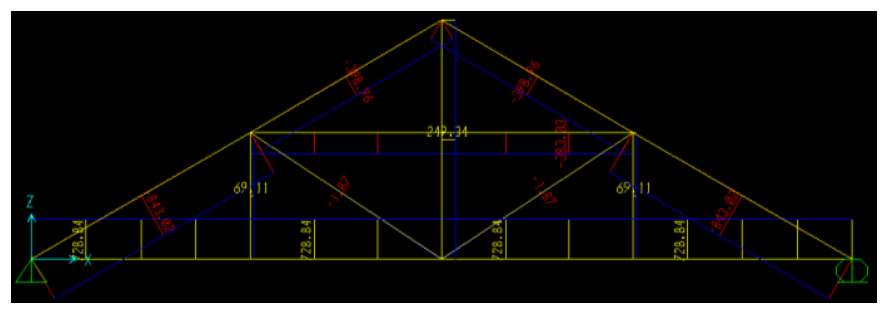

Fig. 4. Loading analysis with 3 combinations of loading

\section{B. Seismic load}

In the event of a minor earthquake, buildings should not be damaged either in non-structural components (cracked walls, falling tiles and ceilings, broken glass, etc.) and structural components (cracked columns and beams, collapsed foundation, etc.) In the event of medium earthquake, the buildings may suffer damage to its non-structural components, but the structural component must not be damaged [7]. This is the basic philosophy of earthquake-resistant buildings and applies to all types of buildings, including the construction of house buildings.

In order to assess the feasibility of the structure of the house, there was a calculation of the earthquake load conducted. Merauke, based on the earthquake area map of SNI $1726: 2012$, is in region 3 with earthquake data of Ss (base rock acceleration in the period of 0,2 seconds) $=0.15 \mathrm{~g}$ and $\mathrm{s} 1$ (rock acceleration in the period of 1 second) $<0.05=0.04 \mathrm{~g}$. Since Merauke is included in the area with soft soil category, then, based on the SNI 1726-2012 site coefficient table, the Fa (vibration amplification factor in the period of 0,2 seconds) is 2,5 and $F v$ (vibration amplification factor in the period of 1 second) is 3.5. Thus, the resulted spectrum response design is shown in table 2 and the spectrum response diagram is shown in Figure 3.

From the calculation of earthquake load data (table 1), T1 (natural vibration time) is 0.1 so as to produce a nominal shear load of $\mathrm{V}=62,65 \mathrm{Kg}$.

\section{Ring balk}

Ring balk in kancingan house is a structure that functions to forward lateral loads from the roof to the structure column. In kancingan house that became the focus of the research, the ring balk uses 8/8 size meranti wood with Orthotropic Component (Meranti) for beams, with the following properties: Density $0.9-0.6 \mathrm{kN} / \mathrm{m} 2 \sim 9 \times 10-4 \mathrm{~kg} / \mathrm{cm}^{2}$, Absolute Bending Strength :>1100 kg/cm2, Absolute Compressive Strength: 650 - $425 \mathrm{~kg} / \mathrm{cm} 2$, Elastic Modulus: 1.00 X $105 \mathrm{~kg} / \mathrm{cm} 2$, Fiber-Parallel Bending Stress ( $\sigma \mathrm{lt} / /): 100$ $\mathrm{kg} / \mathrm{cm}$, Compressive and Tensile Strength ( $\sigma \mathrm{tk} / /, \sigma \mathrm{tk} / /): 85$ $\mathrm{kg} / \mathrm{cm}$, Fiber-Perpendicular Stress $\left(\Sigma_{\mathrm{tk} \perp}\right): 25 \mathrm{~kg} / \mathrm{cm}$, FiberParallel Shear Stress $(\tau / /): 12 \mathrm{~kg} / \mathrm{cm}[8]$.

Based on the results of SAP 2000 analysis (see figure 5), the maximum moment due to the seismic load on the beam is $39,26 \mathrm{~kg} / \mathrm{m}$ and the bending resistance on the $8 / 8$ beam is $1795,2 \mathrm{~kg} / \mathrm{m}$.

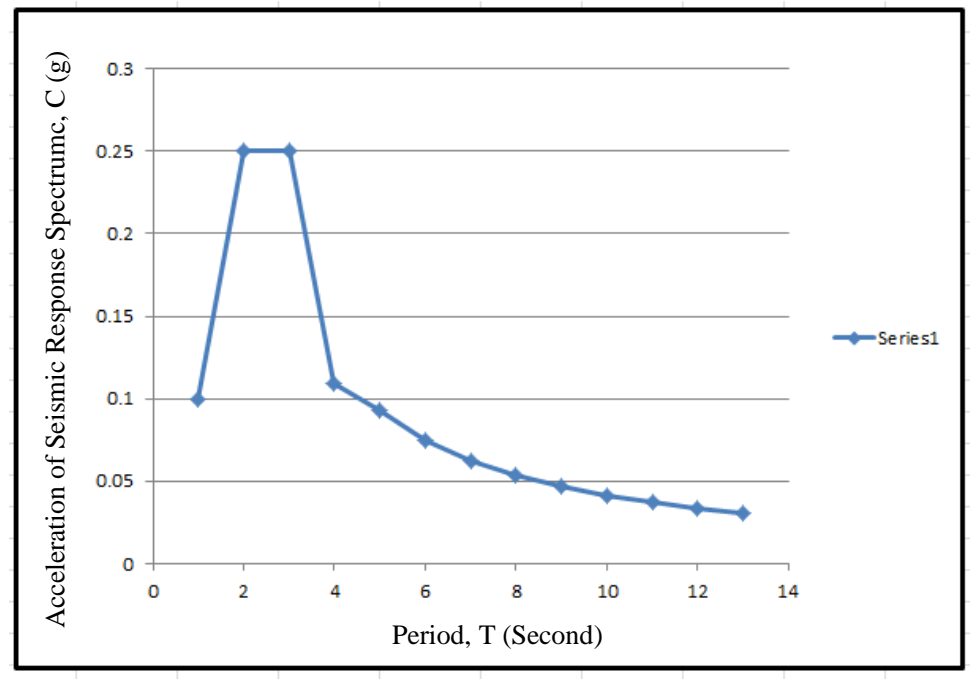

Fig. 5. Diagram of Seismic Response Spectrum for Merauke City

TABLE II. The SEISMic Response SPECTRUm DESIGN FOR MERAUKE CITY

\begin{tabular}{|c|c|}
\hline $\mathbf{T}$ & $\mathbf{C}$ \\
\hline 0 & 0,1 \\
\hline $\mathrm{T} 0$ & 0,25 \\
\hline $\mathrm{Ts}$ & 0,25 \\
\hline 0,85 & 0,1094 \\
\hline 1 & 0,093 \\
\hline 1,25 & 0,0744 \\
\hline 1,5 & 0,062 \\
\hline 1,75 & 0,05314 \\
\hline 2 & 0,0465 \\
\hline 2,25 & 0,04133 \\
\hline 2,5 & 0,0372 \\
\hline 2,75 & 0,03382 \\
\hline 3 & 0,031 \\
\hline
\end{tabular}




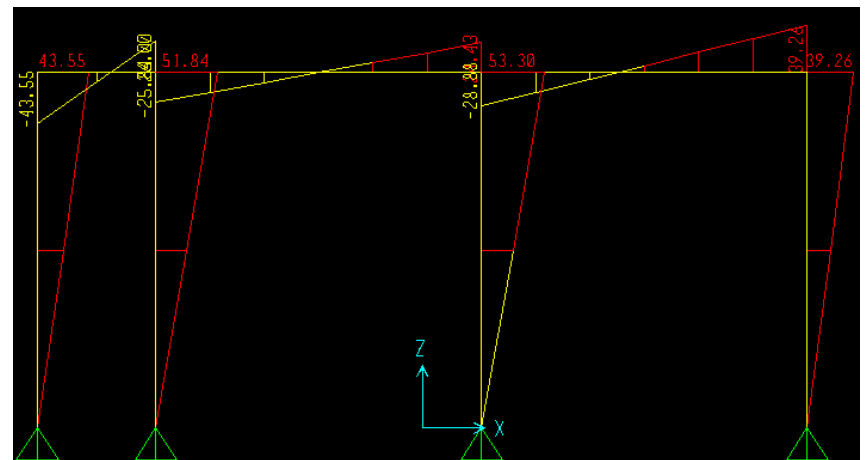

Fig. 6. Moment occurred due to seismic load

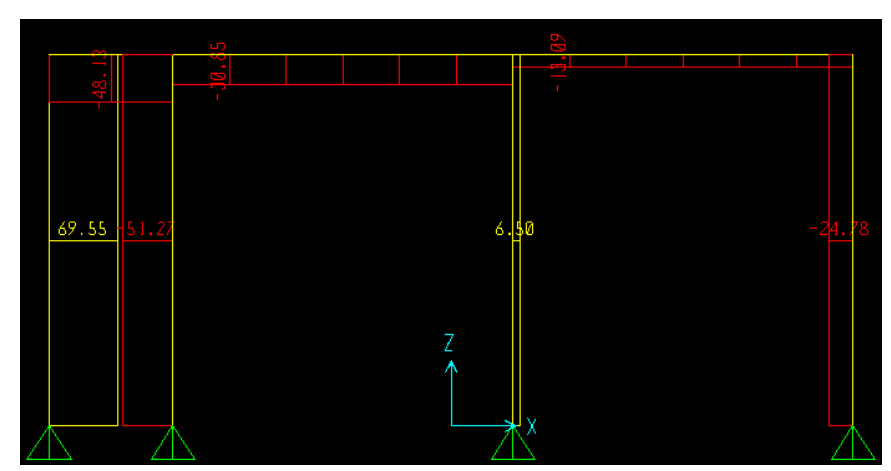

Fig. 7. Shear force due to seismic load

\section{Column}

Columns in kancingan house function as structural components that withstand axial compressive loads and forward them to the foundation. In kancingan house, the column used is made of $8 / 8$ type meranti wood, see figure 1 , with the following properties: Density: $0.9-0.6 \mathrm{kN} / \mathrm{m} 2 \sim 9 \mathrm{x}$ $10-4 \mathrm{~kg} / \mathrm{cm} 2$, Absolute Bending Strength :>1100 kg/cm2, Absolute Compressive Strength: 650 - $425 \mathrm{~kg} / \mathrm{cm} 2$, Elastic Modulus: $1.00 \mathrm{X} 105 \mathrm{~kg} / \mathrm{cm} 2$, Fiber-Parallel Bending Stress $(\sigma \mathrm{lt} / /): 100 \mathrm{~kg} / \mathrm{cm}$, Compressive and Tensile Strength ( $\sigma \mathrm{tk} / /$ , $\sigma \mathrm{tk} / /): 85 \mathrm{~kg} / \mathrm{cm}$, Fiber-Perpendicular Stress $\left(\Sigma_{\mathrm{t} \perp \perp}\right): 25$ $\mathrm{kg} / \mathrm{cm}$, Fiber-Parallel Shear Stress $(\tau / /): 12 \mathrm{~kg} / \mathrm{cm}$. Based on the results of SAP 2000 analysis (see Figure 5), the maximum moment due to seismic load on the column is $53,30 \mathrm{~kg} / \mathrm{m}$ and the bending resistance on the $8 / 8$ column is $1795,2 \mathrm{~kg} / \mathrm{m}$.

In order to determine the ability of the column to distribute the load to the foundation, a calculation was conducted to find the compressive force on the column due to roof load with a result of $615.72 \mathrm{Kg}$ and the slenderness ratio is $\mathrm{Le} / \mathrm{d}=25>50$ and the stability factor is $\mathrm{Pu}=\lambda \times \Phi \mathrm{c} \times \mathrm{P}^{\prime}=11010,96 \mathrm{~N}$.

\section{Discussion}

Based on the results of the calculation of bending stress control, it was found that the bending stress works on the trestle in kancingan house using strong wood materials class E15 was smaller than the actual bending stress of the strong wood materials class E15 or olt $=\mathbf{2 8 5 , 8 1 9} \leq \mathbf{F b}=\mathbf{1 1 0 0}$ $\mathbf{k g} / \mathbf{c m}^{2}$. For bending control, with the condition of $\boldsymbol{f} \mathbf{x} \leq \boldsymbol{f}$ permit $=(1 / 200 \mathrm{~L})$, the structure of trestle of kancingan house in this research of $\boldsymbol{f} \mathbf{x}=\mathbf{1 2 , 6 4} \mathbf{m m}<\mathbf{1 3 . 7 5}$ meets the requirement. Whereas, for the tensile resistance of the trestle, the value is corrected by $8,096 \mathrm{~kg}$ which is greater than the tensile force on the trestle or $\mathbf{T}^{\prime}=\mathbf{F t} \mathbf{t}^{\prime} \times \mathbf{A n}=\mathbf{8 , 0 9 6}>\mathbf{7 . 2 8}$ tons. The slenderness ratio of the compressive beam or Le/d of 11,428 meets the slenderness requirement of $<50$ and the stability factor $\mathrm{Pu}$ is greater than the compressive strength on the beam. In general, the structures of roof frame and trestle in kancingan house can receive the loads on the roof and the trestle. This is possible because the wood materials also have compressive and tensile strength, so that the timber trestle is still an option in designing buildings, especially for roof structure [9]. The mechanical property of wood is the ability of wood to withstand external load. External load is the force of external object that has a tendency to change the shape and size of object.

In the ring balk of kancingan house building, the bending resistance with meranti wood properties is greater than the maximum moment due to seismic load or $\mathrm{M}^{\prime}=1795,2 \mathrm{Kg} / \mathrm{m}>$ $43,55 \mathrm{~kg} / \mathrm{m}$. Wood has resistance to load that is perpendicular to the fiber or parallel to the fiber and wood is categorized as elastic material so that it is still an option in selecting materials for earthquake-resistant buildings.

Columns are components of a building structure of which main task is to support the vertical compressive axial loads. In other words, the column must be calculated to support the compressive axial loads with certain eccentricity [10]. In the columns of kancingan house, the $8 / 8$ column meets the requirements of the slenderness ratio, namely Le/d $=25>50$ with a stability factor greater than the compressive force on the column or $M^{\prime}>P$. For the feasibility of the structure in receiving the seismic force, the calculation of bending resistance due to seismic force in the column obtained $M^{\prime}>M$ max or the $8 / 8$ timber column construction in kancinga house of the roof is able to bear the seismic load that occurred in region 3 based on the earthquake map area according to SNI 1726:2012.

\section{CONCLUSIONS AND SUGGESTIONS}

In general, the construction of kancingan house can bear the loads on the building. The roof load distribution is carried out by ring balk and the columns meet the predetermined requirements. This is possible because the wood materials have resistance to loadings due to the mechanical properties which also have compressive and tensile strength. In kancingan house, even though the main structure is made of wood, the wall is made of bricks, so that the appearance of the building is similar to the appearance of a permanent building in general but more economical in terms of cost because of the minimal use of concrete materials.

For further research, there is a need to compare the structure of kancingan house with other construction, such as steel and concrete constructions. 


\section{ACKNOWLEDGMENT}

The researchers thank the Rector of Musamus University and the academic community of the Faculty of Engineering, especially for Architecture Department.

\section{REFERENCES}

[1] A. Topan, "Analysis Of The Semi-Permanent House In Merauke City In Terms Of Aesthetic Value In Architecture," J. Physics Conference Ser., vol. 1028 , no. 21,2018

[2] Lestari, "Get to know local architecture: Construction of wooden houses on the banks of the river," vol. 3, no. 2, pp. 1-11, 2016

[3] J.A. Tjondro, "Development and Prospects of Wood Structure Engineering in Indonesia," in Semin. and Lokakarya rekayasa Strukt., pp. 1-12, 2014

[4] H. Frick, Building Construction Sciences, $2^{\text {nd }}$ Ed. Yogyakarta: Kanisius,
1997.

[5] Yap, Wood Construction, Surabaya: Bina Cipta, 2001

[6] D. Jazuli, "Comparison of Wood Roof Construction with Concrete Roofs in Terms of Cost," J. "MITSU" Media Inf. Tek. Sipil UNIJA, vol. 2, no. 2, pp. 15-21, 2014.

[7] D. Iswanto, "Study of the Roof Frame Structure of Earthquake Resistant Houses P2KP Assistance," J. Ilm. Peranc. Kota dan Permukim. Enclos., vol. 6, no. 1, pp. 10-21, 2007.

[8] E. Rako, "The Comparative Study Of Shape And Structure Between Tongkonan Traditional House And Bolon Sidabutar Traditional House," Hasanuddin University, 2016.

[9] A. Ginting, "Studs of Bangkirai Wood Beams Connection With Claw Nail Plate," Wahana Tek., vol. 8, no. 2, 2017.

[10] C.M. Rantung, "Beam Evaluation and Columns in Simple Houses," $J$ Sipil Statik, vol. 2, no. 6, pp. 301-309, 2014 